\title{
"Correlating horizontal skills with job specializations based on business sector dynamics in the regional labor markets. The case of Attica region, Greece"
}

\begin{tabular}{|c|c|}
\hline AUTHORS & $\begin{array}{l}\text { Miltiadis Staboulis } \\
\text { Athanasios Tsirikas } \\
\text { Kleanthis Katsaros }\end{array}$ \\
\hline ARTICLE INFO & $\begin{array}{l}\text { Miltiadis Staboulis, Athanasios Tsirikas and Kleanthis Katsaros (2019). } \\
\text { Correlating horizontal skills with job specializations based on business sector } \\
\text { dynamics in the regional labor markets. The case of Attica region, Greece. } \\
\text { Development Management, 17(3), 35-53. doi:10.21511/dm.17(3).2019.04 }\end{array}$ \\
\hline DOI & http://dx.doi.org/10.21511/dm.17(3).2019.04 \\
\hline RELEASED ON & Wednesday, 04 December 2019 \\
\hline RECEIVED ON & Monday, 29 July 2019 \\
\hline \multirow[t]{2}{*}{ ACCEPTED ON } & Thursday, 19 September 2019 \\
\hline & $((c))$ EY \\
\hline LICENSE & $\begin{array}{l}\text { This work is licensed under a Creative Commons Attribution } 4.0 \text { International } \\
\text { License }\end{array}$ \\
\hline JOURNAL & "Development Management" \\
\hline ISSN PRINT & $2413-9610$ \\
\hline ISSN ONLINE & $2663-2365$ \\
\hline PUBLISHER & LLC "Consulting Publishing Company "Business Perspectives" \\
\hline FOUNDER & Simon Kuznets Kharkiv National University of Economics \\
\hline
\end{tabular}

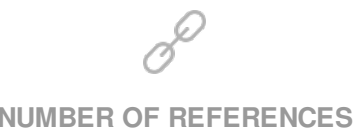

58

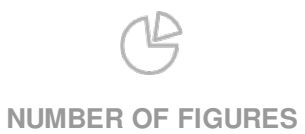

3
NUMBER OF TABLES

4

(C) The author(s) 2021. This publication is an open access article. 


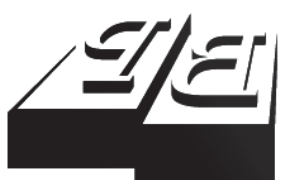

BUSINESS PERSPECTIVES

\section{O}

Publisher

LLC "CPC "Business Perspectives" Hryhorii Skovoroda lane, 10, Sumy, 40022, Ukraine

www.businessperspectives.org

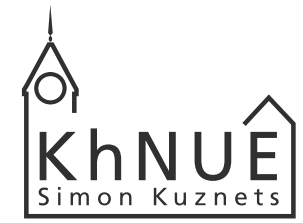

S. KUZNETS KHNUE

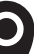

Founder

Simon Kuznets Kharkiv National University of Economics, Nauky avenue, 9-A, Kharkiv, 61166,

Ukraine

http://www.hneu.edu.ua/

Received on: 29th of July, 2019

Accepted on: 19th of September 2019

(c) Miltiadis Staboulis,

Athanasios Tsirikas,

Kleanthis Katsaros, 2019

Dr. Miltiadis Staboulis, Assistant Professor, University of Macedonia, Greece

Dr. Athanasios Tsirikas, Associate Professor, ESCE International Business School, France

Dr. Kleanthis Katsaros, Faculty member, Open University of Switzerland, Switzerland

\section{(c) (i)}

This is an Open Access article, distributed under the terms of the Creative Commons Attribution 4.0 International license, which permits unrestricted re-use, distribution, and reproduction in any medium, provided the original work is properly cited.
Miltiadis Staboulis (Greece), Athanasios Tsirikas (France),

Kleanthis Katsaros (Switzerland)

CORRELATING HORIZONTAL SKILLS WITH JOB SPECIALIZATIONS BASED ON BUSINESS SECTOR DYNAMICS IN THE REGIONAL LABOR MARKETS. THE CASE OF ATTICA REGION, GREECE

\begin{abstract}
The correlation of horizontal skills and vocational specializations is a major challenge for regional employment policies and national economies. This is because this specific type of correlation is capable of shaping the vocational training model as well as the educational system at a higher level (universities) based on the business sector dynamics.

The purpose of the article is to explore the correlation of horizontal skills and job specializations based on the business sector dynamics in Attica region, Greece.

To achieve that, both quantitative and qualitative approaches were used. In terms of the quantitative research, a field research was conducted to collect primary data on a sample of companies the needs for horizontal skills and one-digit (ISCO-Codes) specializations are explored and recorded. Emphasis was placed on the recording of vacancies as well as jobs that are difficult to be filledin in the Attica region; their quantitative and qualitative characteristics were also analyzed.

The results of the quantitative analysis are confirmed by the qualitative research findings, following the logic of the triangulation research methodology. Triangulation was originally proposed in social sciences to increase the credibility and validity of research findings. In other words, it is the use of more than one research techniques in the study of the same research field, each used to verify the results of the other.

The methodology used in this research is innovative due to the use of geographic information systems (GIS).
\end{abstract}

Keywords

labor market, soft skills, vocational specializations, job market needs, triangulation

JEL Classification

$\mathrm{O} 15, \mathrm{O} 21, \mathrm{P} 48$

Мілтіадіс Стабуліс (Греція), Атанасіос Цирікас (Франція), Клеантіс Кацарос (Швейцарія)

\section{АНАЛІЗ КОРЕЛЯЦІЙНОГО ЗВ'ЯЗКУ МІЖ ГОРИЗОНТАЛЬНИМИ НАВИЧКАМИ ТА СПЕЦІАЛІЗАЦІЕЮ ПРАЦІ НА ОСНОВІ ДИНАМІКИ БІЗНЕС-СЕКТОРУ НА РЕГІОНАЛЬНИХ РИНКАХ ПРАЦІ НА ПРИКЛАДІ АТТИКИ (ГРЕЦІЯ)}

\section{Анотація}

Аналіз співвідношення горизонтальних навичок з професійними спеціалізаціями є головним викликом для регіональної політики зайнятості та національної економіки, оскільки цей специфічний тип кореляції здатний сформувати модель професійної підготовки, а також освітню систему на вищому рівні (університетів) на основі динаміки бізнес сектору.

Метою дослідження $є$ аналіз кореляційного зв'язку між горизонтальними навичками, спеціалізацією праці та динамікою ділового сектору в Аттиці (Греція). 
Для досягнення мети використано кількісний і якісний підходи. Проведено польові дослідження для збору первинних даних про вибірку компаній, досліджено та зафіксовано потреби в горизонтальних навичках та однозначних (ISCO-кодах) спеціалізаціях. Увагу зосереджено на обліку вакансій і на робочих місцях, які важко заповнити в регіоні Аттика, та на аналізі їх кількісних і якісних характеристик.

Результати проведеного кількісного аналізу підтверджуються даними якісних досліджень, проведених відповідно до методології тріангуляційного дослідження. Спочатку метод тріангуляції застосовувався в соціальних науках для підтвердження та обгрунтованості результатів досліджень. Інакше кажучи, це використання більш ніж однієї методики у вивченні однієї й тієї ж галузі застосування, кожна з яких використовується для перевірки результатів іншої.

Використана в даному дослідженні методика є інноваційною завдяки використанню геоінформаційних систем (ГІС).

$\begin{array}{ll}\text { Ключові слова } & \text { ринок праці, комунікаційні навички, професійна спеціалізація, потреби ринку } \\ \text { праці, тріангуляція } \\ \text { Класифікація JEL } & \text { O15, O21, P48 }\end{array}$

\section{INTRODUCTION}

\section{Aim and targets}

In the last decades, it has been evidently clear that the development of systems and mechanisms is necessary in order to track and analyze the changes which take place within the economic systems, predicting in parallel the changes in the numbers and the content of labor vacancies and also their long-term differentiations regarding the qualitative characteristics (i.e. knowledge, skills and capabilities), being based though on the regional developments and giving emphasis on covering the future demands of labor market (Caloffi \& Mariani, 2011). The timely provision of information on the forthcoming changes empowers the efforts of the public and private sectors towards the implementation of activities which can contribute to the more efficient adjustment of new demands in the recent status of human resources but also in the economic systems, in a more broaden view.

However, this issue does not concern only the Greek economic system. In many European Union countries, we can already identify similar mechanisms which track the changes and developments in labor markets, having as an ultimate goal the provision of timely information related to the implemented changes, towards all involved stakeholders and involved parties in the function of labor markets (Rihova, 2016; Matheus et al. 2018).

In this context, the Ministry of Labor, Social Security and Solidarity of Greece instructed the National Labor and Human Resources Institute (NLHRI hereafter) to draw up the National Action Plan for diagnosing the labor market needs at national and regional level, through the function of the respective mechanism which requires cooperation between the NLHRI and the administrative territories of Greece. The Action Plan was drawn up by the NLHRI within one month, received the agreement of the Ministry and the social partners and was submitted for approval to the European Commission, which in the end, approved it (NLHRI, 2018).

The Labor Market Needs Analysis Mechanism (LMNAM hereafter) was created by the Ministry of Labor, Social Security and Social Solidarity in 2016 following an Action Plan adopted by the European Commission in 2015. The LMNAM consists of two pillars. The first pillar concerns data on employment, unemployment and entrepreneurship, collected from multiple sources and was organized and visualized in a way that it enables interactive browsing and searching for information. The second pillar concerns analyzes of these data by the NLHRI, on one hand, to highlight the most dynamic professions and their characteristics and, on the other, to facilitate the design of evidence-based active policies targeted at specific sectors, occupations, demographic characteristics, qualifications, skills and geographic regions (http://lmds.eiead.gr/?page_id=789).

In conclusion, the aim of this research paper is to answer the following:

1. How many final vacancies exist in the Attica Region?

2. In which business sectors and which professions?

3. The characteristics of the vacancies and the enterprises in which they are recorded.

4. For how long and why the positions remain empty? 
5. The employment / occupational criteria at the professional / sectoral level.

6. The dynamics of sectors and professions and the conditions for increasing employment in professions and industries.

7. Which are the "horizontal" and / or professional skills in which there is a shortage in the region of Attica?

8. In which professions and disciplines we note a shortage of those identified skills?

For the purpose of conducting the research, a questionnaire delivered from NLHRI was used to identify the needs of enterprises in job specializations and related skills. The questionnaire was addressed to general managers or to Human Resource managers of large enterprises and to the owners of smaller enterprises. The research covered enterprises in all sectors of economic activity, with the exception of the following: public administration and defense, extraterritorial organizations, households offering services.

The quantitative results of the research were also verified by the use of a qualitative approach, thus we implemented the basic principles of the triangulation methodology (Morse, 1991). Triangulation was originally proposed for use in social sciences in order to increase the reliability and validity of research findings. In other words, it is the use of more than one research technique in the study of the same research field, each of which is used to verify the results of the other. According to Morse (1991), the use of a mixed method in the same study is particularly important, and defines methodological triangulation as: "the use of at least two methods, usually qualitative and quantitative, in the research of the same research problem".

\section{The framework of diagnosing labor market needs and the new approach through the use of geographic information systems}

The Labor Market Needs Diagnosis Mechanism (LMNAM) is a structural reform in the direction of the design and implementation of policies that help to meet real labor needs and provide substantial support to workers and youth (Pines et al., 2011). It is a tool that helps states to design policies in order to reduce unemployment.

The results of the mechanism allow for the first time for both, states and ordinary citizens, to have a direct, comprehensive and detailed picture of the labor market and its trends: what professions and which business sectors create new jobs? In which Regions, Regional Units and municipalities within the country? Where precisely are there any weaknesses and lags? (Rihova, 2016). The LMNAM is based both on the use of national databases and their combination, as well as on field researches (NLHRI, 2018).

However, the innovation of the tool used in this study lies in the use of geo-location data used in decision-making systems in many scientific disciplines. Geotargeting data helps to ensure a better and safer decision-making process (Goodchild, 2010), as they allow users to view, analyze and understand patterns and relationships, as well as to create interactive queries, process data on maps, and present the results of all these functions on maps, tables, and graphs (Goodchild, 2010). GISs are generally considered as a special type of decision support systems (DSS). For example, a typical GIS application allows decision makers to choose a map location, and then the application (GIS app) is able to produce demographic information about the population within a particular radius of the location (Fuller \& Bradbard, 2009).

GIS applications can be found in many activities and sectors (eg transport / logistics, telecommunications, agriculture, accident analysis, crime, etc.) and are sometimes linked to entrepreneurship. For example, GIS has been utilized in Rosenthal \& Strange (2005) for mapping the geography of entrepreneurship in New York, but also by Think London Organization, which is investing in business activities, as a way of identifying the best places to invest. According to the GIS Lounge (2017), there is clear evidence that entrepreneurship success is often driven by significant spatial patterns, particularly in terms of concentration of work, knowledge and investment opportunities.

In order to solve more complex policy problems, GIS systems are combined with Decision Support Systems (DSS) (Sugumaran \& Degroote, 2011). A DSS is a computerized information system used to support decision-making in an organization, business or even government, allowing for the analysis of a large volume of data and the 
extraction of information that can be used in decision-making to resolve problems (Marakas, 2002; Jao, 2010). The benefits of decision support systems include more sophisticated decision making, timely problem solving, and improved effectiveness to deal with the problems of rapidly changing variables.

Like GIS, DSS applications cover a variety of areas, from aviation monitoring, transport safety, clinical diagnosis, weather forecasting, business management, and internet search strategy. Indeed, the implementation of DSS as spatial decision support systems is sometimes referred to as Policy Support Systems (PSS) as they combine elements of the DSS and GIS systems (Keenan, 2008; Sugumaran \& Degroote, 2011). These systems are concerned with how to integrate spatial information into a decision-making environment in order to optimize the decisionmaking process (Rodrigues et al., 2011).

\section{LITERATURE REVIEW}

\subsection{Regional development and labor markets}

The main objectives of regional development policies are to exploit the development potential of cities and regions within countries and to reduce regional disparities (Caloffi \& Mariani, 2011).

The exact developmental approach chosen will depend on the region's specific characteristics, local preferences and objectives as well as the availability of resources. One of the most important objectives in any such effort is to implement regional development policies is job creation (Bartik, 1991). In addition, regional development strategies help local economies to adapt to ever-changing circumstances by maintaining social balance and by making best use of social, economic and environmental resources within each region.

Taking into account the dependence of the final economic activity on the job, it can be understood that the higher the participation of labor in the final product, the more prosperous the prospects for economic growth. This proposal is based on the functioning of the overall macroeconomic circuit. More specifically, the increased employment rate strengthens the purchasing power of employees and keeps consumption at significant levels, thus providing guarantees for total active demand, a positive asset for investment (Kourliouros, 2009). This cyclical activity creates economic growth, which is based both on capital and on work. Therefore, this prospect fights unemployment by putting it aside, or in any case close to a natural rate of around 6\% (Lianos \& Benos, 1998).

The development of the labor market thus directly affects economic growth. However, the development of the labor market is mainly linked to entrepreneurship, in a sense that effective entrepreneurship is the basis for consolidating labor demand. It is generally accepted that modern economies are developing economically by investing. Investments create, on the one hand, increased aggregate demand and, on the other hand, create conditions for increased supply, especially when they are oriented towards productivity increase. In other words, it can be argued that the labor market is directly linked to investment and thus to production activities (Kalogirou, 1998).

\subsection{Regional development and growth based on innovation}

Innovation is defined as the process that allows the integration of technology or know-how, which leads finally to the development of new production techniques, new industrial products and services (Arkolakis et al., 2018). In this context, innovation goes beyond Research and Technological Development and covers a range of activities, including technology transfer, planning, quality assurance and control, organization, education and financial services (Aghion et al., 2019). Modern economies are in a phase of change from industrial to post-industrial, economies that increasingly rely on the production, distribution and use of knowledge and information (Acemoglu et al., 2018). Technology is now the main motivator of productivity and economic growth. Innovative activities based on new information and communication technologies create new or better products and services and change the structure of the economy. 
The development of information and communication technologies (ICT) creates new divergences between regions as far as it concerns the access to the information society (Zheng et al., 2018). The strong impact of network development (NET-Economy, digital and mobile online services) can contribute to the reverse of geographic and economic isolation of administrative regions and promote equal opportunities for their inhabitants (Setiawan et al, 2018).

\subsection{Innovation and knowledge}

Automated production systems and increasing demand for intellectual work have led more and more companies to hire "minds" rather than "hands" (Manning, 2013).

Therefore, while growth and competitiveness remain key political objectives, what has changed in recent years is the factors that lead to them (Wilgaard, 2019). It is outdated that the reduction in labor costs is the method of ensuring the sustainability of enterprises in today's knowledge economy (Du Plessis, 2007). On the contrary, as most people realize, in the context of globalization and international competition, technological development and innovation ensure the viability of an enterprise and become crucial in every corner of the planet. According to Schumpeter, innovation can take various forms, such as the introduction of a new or better quality product, the use of a new production process or the acquisition of a new input, the opening of a new market, or the realization of a new form and structure of an enterprise (Schumpeter, 1934). In other words, the concept of innovation presupposes the replacement of "old" production methods with "new" innovative actions and is the cornerstone of the knowledge economy. It is no coincidence also that innovation is defined by many modern economists as "knowledge in practice".

So if we define innovation as the use of new knowledge in order to offer a new product or a new service that the market demands, innovation is today one of the most important parameters of achieving economic growth and that is why it is placed in a high priority on governments' political agenda (Montoya \& Penalvo, 2018). It has also to be noted that the differences in competitiveness and per capita income observed between national economies, can at least be attributed to different levels of innovation activity (Tian et al., 2018).

At a time when rapid technological developments lead to knowledge-based production processes and products, the management of innovation is central to national policies in developed countries. Knowledge management should take place in every part of the knowledge chain, from its creation to its diffusion and its transformation into innovative actions, as well as its exploitation by enterprises. In this process three factors are projected as defined by Papa et al. (2018):

1. Investments in basic research through governmental policies that support and fund research activities. Alternatively, worth to mention the contribution of private in $\mathrm{R} \& \mathrm{D}$ investments.

2. The size and quality of the country's research potential and the level of higher education (universities) in technological disciplines, but also in disciplines related to administration, organization and production.

3. Infrastructure in ICT industry, which among other things, allows direct communication and interconnection and the extraction of large volumes of data.

Therefore, in the knowledge economy, investing in human resources and in particular the constant update of skills, but also the establishment of lifelong learning activities are of crucial importance (Papa et al, 2018). The economic, social and cultural changes that take place daily and the increasing importance of knowledge in the production processes, create the need for the continuous development of different skills or their upgrading at all stages of employees' working life (Barley et al, 2017). In order to achieve this, the objective of the business, as mentioned above, should not be the finding or maintenance of cheap labor but instead to upgrade the quality of work through a constantly trained workforce (Kluve, 2010).

In today's labor market, specialization on one sector for a lifetime is no longer the case, as the form and structure of the various professions or business sectors are rapidly changing and training needs on new skills are constantly being created (Wang \& Guo, 2018). 


\subsection{The sector dynamics in Greek economy and the inputs-outputs methodology}

The "over-growth" period of the Greek economy after the country's entry into the eurozone area and before the start of the global financial crisis (2007), corresponds to a period of high current account deficits and deficits in the balance of goods and services. Economic growth in the period 2000-2010 was mainly driven by non-tradable goods and services - not exposed to international competition. Income growth in the non-tradable sector increased the demand for tradables from abroad, reproducing the high deficits in the balance of goods and services (Ozturk \& Sozdemi, 2015).

Current account deficit coverage should be funded with an equal net inflow of capital. Prior to the crisis, the bulk of the current account deficit in the Greek economy was financed by financial inflows recorded in the financial account (Papadimitriou et al. 2015).

In the context of the global financial crisis, under conditions of reassessment of credit risks in the financial sphere, this funding has been abruptly stopped. The coverage of the current account deficit in the Greek economy after 2010 is mainly based on the official support of the "Troika" Mechanism. The recession, which the "MOUs" (Memorandum of Understanding) implied, led to a sharp decline in profitability, among other things due to the activation of the under-consuming sub-component of the crisis. This under-consuming background, however, is only a form of appearance, in the conjuncture of the international economic crisis, of the deeper structural and developmental problem of the Greek economic system, especially in the 2000s, as expressed in the developmental model, based on (and reproducing) high deficits in current account balance. This kind of economic growth has come to its limit with the outbreak of the global economic crisis (Varoufakis, 2017).

According to Oikonomakis \& Markaki (2016), the Greek economy is a relatively "extrovert" economy within the EU-EMU as it displays relatively weak domestic production interconnections, while high specialization, relatively low level of industrial and technological development and growth (and productive structure dominated from small businesses), "unfavorable" relative income elasticities of demand, and therefore relatively low international competitiveness, which is reflected in unfavorable trade conditions and trade deficits.

In this framework of the general economic context, it is interesting to study the dynamics of the business sectors in order to redefine the field of production reconstruction on the basis of the dynamics of business sectors and professions (Varoufakis, 2017). In particular, we find relevant data within the study of the LMNAM published by the NLHRI (2018), which presents a methodological framework for the analysis of the dynamics of the professions and business sectors of the Greek economy. In this framework, researchers are given the opportunity to study the dynamics of occupational categories (three-digit coding) for the whole country in the period 2013-2017, based on data derived from the Labor Force Survey of ELSTAT (Hellenic Statistical Agency). By choosing number classification, people can easily identify the ascending or descending rankings of the professions in terms of dynamics, absolute and percentage change, as well as their classification (i.e. as high, medium and low dynamics).

As shown in the study (NLHRI, 2015, 2018), with regard to professions, the highest dynamics is shown in employees with a broaden area of duties, sellers in shops, waiters and food processing assistants. In particular, in the rating scale of dynamics from 1 to 10 , employees with a broaden area of duties are evaluated with 10, sellers in shops with 9 , waiters with 8 , and food processing assistants with 8 . In the average of professions dynamics, with a score of 6, we have the professionals in financial and mathematical sector, child carers and teaching assistants, and processing workers. Finally, in the low dynamics professions, the largest number of specializations is recorded, with most of them rated with 3 and 2, whereas only market - oriented farmers are rated with 1.

With respect to the business sectors, the methodological framework shows that the highest dynamics is shown by Restaurant and Mobile Catering units with a score of 10. In the sectors of average dynamism, the long-term farming activities with 9, hotels and similar accommodation with 8 and retail trade of food, beverages and tobacco in specialized stores with 7, retail of other goods in specialized stores with 6 and sports activities with 6 (NLHRI, 2015). 


\subsection{The input-output method}

The methodological framework mentioned is an example of the application of the input-output methodological approach. Input-output analysis is a methodological tool used to calculate the structural changes caused to the economy of a region or a country after the implementation of developmental policies. This analysis falls under the category of simultaneous equations models and describes the flow of goods or services between the individual business sectors of an economy at a given point in time (eg one year). It is based on the theoretical framework developed by Leontief in the mid-1930s, while in its practical form the Leontief model, like other contemporary models of general equilibrium, was based on the scientific work of Quesnay and Walras (Yang \& Miller, 2008).

In its more simplified form, the input-output model is a method of systematically quantifying the reciprocal productive relations between the various business sectors or sectors within the framework of an economic system. Input-output analysis interprets the operation of the economic system by making use of the interdependence of its economic sectors. It has been established as a particularly useful tool of the economic science and was used to analyze the impact on the economy at national, regional and local level following investment or other economic changes (Walras, 1954, 1992; Yang \& Miller, 2008).

A key element of the input-output model are the technological coefficients, while the use of the model presupposes their long-term stability. Researchers say that technological factors remain stable for a period of 5-10 years, which requires a stable correlation between the end product of each industry and its inputs (Yang \& Miller, 2008). For longer periods it is necessary to adapt the tables of technological coefficients. The more developed the economy of a country and its regions, the smaller are the changes in the "mix" of inputs used and therefore the changes in technological factors over time.

The main factors influencing the stability of technological factors according to Walras (1993) include: (a) technological changes, (b) changes in the production processes, (c) price changes, (d) changes in the patterns of trade, (e) the creation of new businesses, (f) random factors.

\subsection{Horizontal skills and regional development}

The development of local labor markets can easily have a significant impact on regional development (Scott \& Storper, 1992). Regional development is undoubtedly a spatial determination in the sense that its main object is to study the economic events that take place in a given space (place) within a given time period. In particular, more than just economic events, regional development is concerned about their impact, and indeed on a spatial dimension. In this sense, regional development is a quite different object from national economic development. Regional development can be defined as the process by which the total output of a particular region is increased (Lambrianidis, 2001). Increasing the regional product by improving the income of the inhabitants of a region is probably the most important element of regional development. But in addition to raising income, regional development is a complex process, which ultimately improves the level and quality of life of the inhabitants of the geographical territories. A key feature of regional development is the spatial concentration of economic activities. Selecting the location of businesses, their investments and the employment opportunities they offer, are perhaps the most important features of regional development. This is because they contribute to the existence of economies of spatial concentration at a local level (Mc Cann, 2002). This dimension is, moreover, to emphasize that the structure of regional development is determined to a considerable extent by the sectoral spatial structure of economic activities.

Perhaps the most interesting aspect of regional development is that the geographical distribution of economic activities may show strong variations in space. These differentiations can also arise from the activation of executives in the wider context of the local economic space. The relationship between regional development and the activation of executives in a local labor market highlights the importance of education and training in the labor market and consequently in the local labor market (Mc Cann, 2002). 
One of the most important dimensions of the importance of horizontal skills demonstrates their correlation with socio-economic regional development and individual local production systems. Hence, horizontal human resources' skills play an important role in the ability of businesses, organizations and administrations to continually transform information and knowledge into new sustainable products, services and production processes. Moreover, all of these are being considered in a generalized framework of constant changes in technology and markets to achieve a sustainable competitive advantage (Lambrianidis, 2001; McCann, 2002).

\subsection{The importance of horizontal skills in labor markets and micro-macroeconomic development}

A continuously increasing number of companies around the world identify the need to attract and retain not only skilled workers but also workers who know how to behave, communicate with colleagues and their clients and also are able to deal with certain situations, sometimes irrelevant with their professional core capabilities and hard skills (Korczynski, 2002).

In other words, workers need to possess a range of skills that are not necessarily linked to the tasks they perform every day. Communication skills, self-management and self-awareness, leadership, tolerance of ambiguity, competitiveness, decision-making, are just a few of the horizontal skills that are in high demand from employers. The most common term used to describe these skills is "soft skills" (Field \& Mawer, 1996; Korczynski, 2002).

Employees' horizontal skills can improve their organizational competitiveness and become a set of non-replicable capabilities that in turn generate a sustainable competitive advantage at both the micro and macro level (Spilsbury, 2002; Turner, 2001). Moreover, the importance of horizontal skills is underlined by the fact that most of the positive judgments received by managers in their professional careers are directly related to the use and anticipation of horizontal skills rather than the use of task-based knowledge (Becker et al., 2001).

In this context, human resources departments have begun to link horizontal skills to employee performance and incentives, or even compensation packages (Cosh et al., 2003) while the modern perception of horizontal skills has dramatically changed the selection and recruitment processes (Hospitality Training foundation, 2000). Personality traits, business ethics, communication capabilities, tolerance to uncertainty, critical thinking, adaptability, empowerment, self-defense, teamwork and trust are among the most important horizontal skills that make the difference between workers and can no longer be ignored or underestimated compared to the hard skills that used to define the employees' suitability for a specific job position (Burns, 1999).

One step further, most organizations do not just seek for employees by defining the need for specific basic professional skills. The modern concept of recruitment involves matching all hard and soft skills with the requirements of the position (Howell et al. 1991; Turner \& Lawry, 2001). The enormous workplace reforms that have taken place over the last decades, both at a micro and macro level, lead to a new understanding of the importance of horizontal skills, emerged in the field of business management science (Burns, 1999). In this respect, many studies have been carried out that emphasize the relationship of employees' skills with individual and team performance (Nickson et al., 2003).

A large number of scientists focused on the research of horizontal skills and in particular on the relationship between skills and job performance. Several industries and business sectors have attracted the interest of researchers such as Information and Communication Technology (ICT), Education, Industry, Construction, Health and Retail Markets. However, a critical analysis of the literature reveals that most of the studies focused only on certain skill elements and fail to explain which skills and under which parameters can affect employees' performance. For instance, there are studies mainly in the construction sector, trying to explain the importance of different skills in improving individuals' performance. In addition, several other studies have highlighted various problems in strategic industrial sectors, which stem from the lack of horizontal and interpersonal skills.

According to Crowley et al. (2000), teamwork, communication, planning and organizing are considered as prominent amongst the critical skills for performance improvement. Thus, technical workers who are able to integrate 
specific horizontal skills into their daily tasks, can be compared on an equal basis with other workers in the knowledge industry. A reform of the workplace in this research, was focused on the development of various skills, which in turn revealed that communication, teamwork, planning, organization and, to a lesser extent, collecting, analyzing and organizing information play an important role. In addition, the same research, when focused on middle and senior executives, revealed that these executives spend considerably a lot of their time on competencies such as communication, problem solving, planning, organizing, collecting and analyzing information.

\section{PILOT RESEARCH METHODOLOGY IN THE REGION OF ATTICA LABOR MARKET}

\subsection{The basic participants in the research and statistical data resources}

The NLHRI research team performed a field research in order to collect primary data from a sample of firms, concerning the investigation and registration of needs in horizontal skills and one-digit specializations (ISCOCodes) in Attica region, Greece. Emphasis was given on registering the vacancies but also on identifying job positions that are hard to be filled, by analyzing their quantitative and qualitative characteristics. In order to perform this research, as already mentioned, the NLHRI questionnaire was used, which was handed out to large firms' general managers and HR heads as well as to owners of smaller firms.

The questionnaire was completed via telephone interview. A web questionnaire was developed for that use, where access was given only to the interviewers. By using the web questionnaire, not only the process of gathering and registering data was accelerated, but also the danger of recurring mistakes during transfer of data from file to file (from written form to an excel file for reasons of unification and from excel file to SPSS for statistical processing) was mostly eliminated.

For initiating the communication with the companies that consist the research sample, NLHRI used the Athens Chamber of Trade data bases. The field research was conducted between 3 and 10 November 2015 and led to the gathering of data from 202, in a total number of 1.850 companies. The final response rate was $11.08 \%$. The layering of the sample was based on three parameters: business sector, administrative region in which the company has it headquarters, and the type of company (SA, Ltd, GP, LP).

However, the allocation of the sector of operation in the sample are not proportional to the allocation in the total population, and the proportional deviation was made on purpose, aiming at increasing the reliability of outcome for the sector with minor population.

To sum up, each sector was seen as an independent population and we aimed at its outmost valid representation in the research. As a general rule, in the sectors with large population the representation in the sample was decreased while in the sectors with smaller population the relevant proportions in the sample were increased. This increases reliability of data in smaller sectors, without causing any significant change in the representation of bigger ones.

After that, the goals of sampling were accounted according to the rest of the parameters (administrative region, number of employees). In essence, for each sector the respective groups were formed, and the necessary sample was defined proportionally.

\subsection{The Triangulation Research Approach}

There are two types of methodological triangulation: (a) the use of more than one tool that generates the same type of data in the study of the same phenomenon and (b) the use of two or more complementary methods in the study of the same sample, to answer the same research questions. This method is useful for checking the validity of a study. It has also been shown that the mixing of many methods balances the weaknesses and strengths of the different methods (Mitchel, 1986). 
In this regard, and for our present research, triangulation will be executed using two different qualitative research tools. The first method to be used is the method of semi-structured in-depth interviews. In any case, the number of interviews required may not be less than three (3) and may, depending on the case, reach fifteen (15) or even twenty (20) interviews. The purpose of these interviews is to verify the findings of the bibliographic research, to highlight new issues and trends in the subject area and to formulate the agenda of the forthcoming group interviews, which is the second method of collecting qualitative data. From these interviews, in line with previous bibliographic research, the list of skills that will be put forward for discussion, evaluation and research in the follow-up group discussion (or discussions) will be drawn up.

\subsection{Descriptive characteristics of the sample}

As aforementioned, in total 202 firms participated to the research, of which $10.4 \%$ were commercial enterprises, followed by hotels, food and catering businesses (8.9\%) and processing businesses (8.9\%).

In addition, firms that participated to the research are based mainly in the Central and Southern sector, amounting to a percentage of $42.6 \%$.

The large percentage of firms (84.2\%) operates in only one store. For the 32 of the firms that operate in more than one stores, the total number of employees working in all stores was registered, amounting to an average of $55 \mathrm{em}-$ ployees and a maximum of 400 employees.

The largest number of employees above 50 years in the firms used in the sample under study is 35 , with an average of 1.52 employees per business. Respectively, the maximum number of employees under 30 years is 100, with an average of 2.83 employees per business.

\section{RESULTS}

\subsection{Quantitative Research}

\subsubsection{Descriptive results of the quantitative research}

Descriptive results of the research are focused on elements concerning working positions and in particular the vacancies, employees' skills and the innovations brought in to the market by each firm.

At first, the change in the working positions of the firms compared to previous semester was investigated. In the majority of firms there were no changes, while the percentage of local stores to have increased the working positions is worth mentioning (24.8\%). On the contrary, the percentage of businesses to have decreased the working positions in comparison to six months ago is $12.9 \%$.

Moreover, the average years employees have been working in one firm was evaluated. The results show that there is a split in this time period, where there are relatively high percentages of employees preserving their job up to one year, from 1 to 3 years, from 3 to 5 years and from 10 years up, while lower seem to be the percentages of employees staying at their job for a period of 5 to 10 years.

In addition, the existence of job vacancies for the local store at the given time was studied. While the majority of businesses $(81.7 \%)$ has no vacancies, there is a percentage of $18.3 \%$ having job openings at this specific time slot.

Following that, questions concerning the profile of these job openings were asked to those 37 firms with vacancies. The greater need is found in professionals and office employees. As to the amount of vacancies, an important number of firms are in immediate need of one employee, while only fewer need more than 3 employees. As to the necessary level of education for the vacancies, firms ask for a minimum of secondary or university level education. As far as it concerns the work experience needed, research has shown that for firms this is not a necessary 
criterion, since they don't ask for previous working experience, while there is a split in the percentages of firms asking for 1, 2 or 5 years of experience. Finally, the working positions remain vacant for a period of time spreading from 1 to 2 months.

Table 1. Professional specializations' vacancies at the local store

\begin{tabular}{|c|c|c|c|c|}
\hline & Frequency & Percentage & Valid Percentage & $\begin{array}{l}\text { Cumulative } \\
\text { percentage }\end{array}$ \\
\hline Senior managers and executives & 2 & 1.0 & 6.1 & 6.1 \\
\hline Professionals & 8 & 4.0 & 24.2 & 30.3 \\
\hline Technical staff and related professions & 4 & 2.0 & 12.1 & 42.4 \\
\hline Office employees & 9 & 4.5 & 27.3 & 69.7 \\
\hline Salesmen and Services staff & 1 & 0.5 & 3.0 & 72.7 \\
\hline $\begin{array}{l}\text { Skilled craftsmen staff and related } \\
\text { professions }\end{array}$ & 3 & 1.5 & 9.1 & 81.8 \\
\hline $\begin{array}{l}\text { Operators of industrial installations, } \\
\text { machinery and equipment and assemblers }\end{array}$ & 1 & 0.5 & 3.0 & 84.8 \\
\hline $\begin{array}{l}\text { Unskilled workers, manual workers and small- } \\
\text { scaled professionals }\end{array}$ & 2 & 1.0 & 6.1 & 90.0 \\
\hline Uncategorised staff & 3 & 1.5 & 9.1 & 100.0 \\
\hline Total & 33 & 16.3 & 100.0 & - \\
\hline Missing & - & 83.7 & - & - \\
\hline Total & 202 & 100.0 & - & - \\
\hline
\end{tabular}

Concerning the change in the working positions in each firm sector for the next trimester, a percentage of $18.3 \%$ considers that there will be an increase in the working positions.

As shown in Figure 1, the most dynamic sector in terms of creating new working positions is the one of "other service provision" activities, ie in the field of personal, creative and cosmetic services as well as wholesale/ retail trade, professional, scientific and technical activities, transportation and logistics.

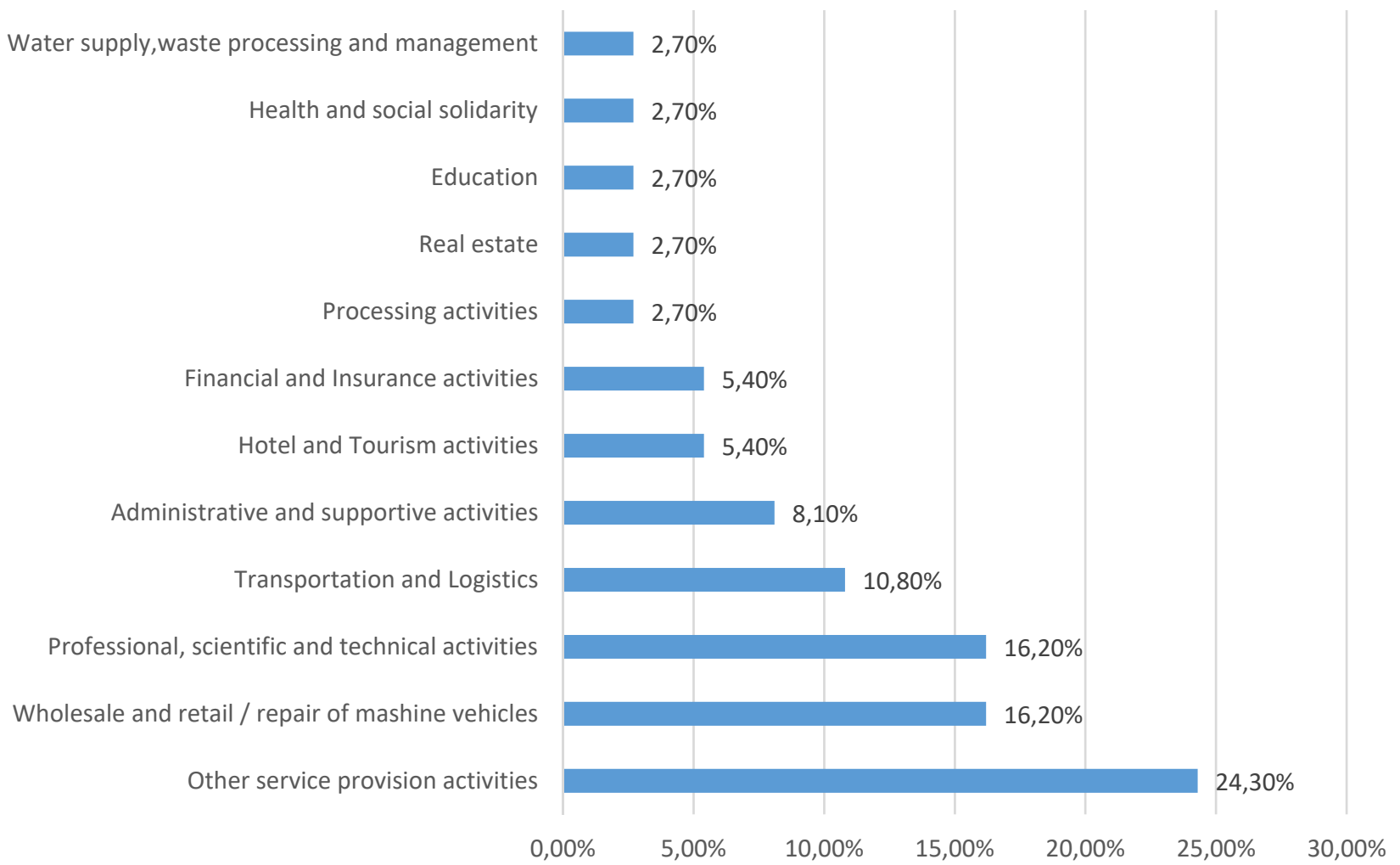

Figure 1. Business sector dynamics with regard to the creation of new job positions 
In the chart below (Figure 2) the regions where the firm owners believe that the working positions will increase in the following three months are depicted. As shown below the most dynamic is the Central Sector of Athens, followed by the Southern and Northern ones. In the remaining regions the percentage of firm owner considering that in their sector new working positions will be created is less than $10 \%$.

Concerning the increase of working positions in the local stores of each firm for the next semester, the majority of firms used in this sample has given negative responses in comparison to the general trend of the sector. However, a portion of the firms used in this research (19\%) (Table 2), considers that the working positions in the firm will increase in the next three months. These firms operate in the areas of professional, scientific and technical activities, and to other service provision activities, in real estate and education. In Figure 3 we also note the sector dynamics in creating new job positions.

Table 2. Percentage of businesses believing that the job positions of the local store will be increased in the next trimester

\begin{tabular}{l|c|c|c|c}
\hline & Frequency & Percentage & $\begin{array}{c}\text { Valid } \\
\text { percentage }\end{array}$ & $\begin{array}{c}\text { Cummulative } \\
\text { percentage }\end{array}$ \\
\hline Yes & 38 & 18.8 & 18.8 & 18.8 \\
\hline No & 144 & 71.3 & 71.3 & 90.1 \\
\hline Do not know/Do not answer & 20 & 9.9 & 9.9 & 100 \\
\hline Total & 202 & 100 & 100 & \\
\hline
\end{tabular}

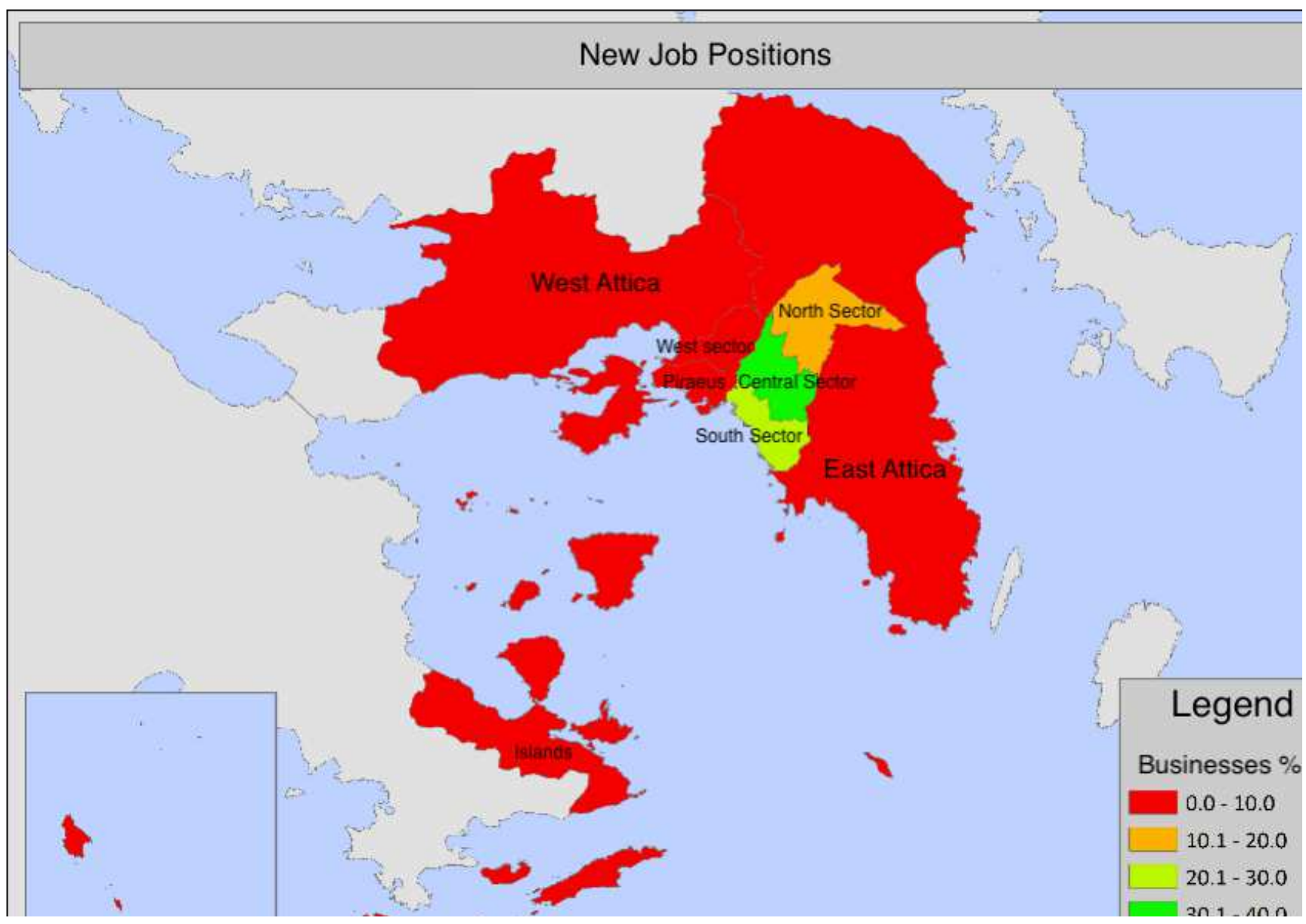

Figure 2. Working positions percentage increase per sector and per region 
Power supply, natural gas, steam and airconditioning

Communications and Informations

Arts \& Entertainment

Hotel and Tourism activities

Constructions

Administrative and supportive activities

Processing activities

Wholesale and retail / repair of mashine vehicles

Health and social solidarity

Financial and Insurance activities

Transportation and Logistics

Education

Real estate

Other service provision activities

Professional, scientific and technical activities
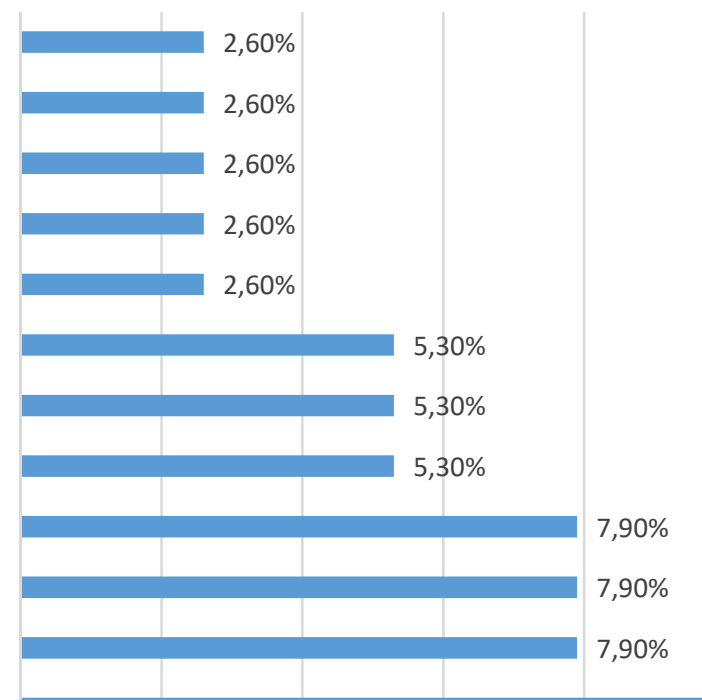

$10,50 \%$

$10,50 \%$

Figure 3. Sectors dynamic in creating new job positions in local stores

\subsubsection{Most popular professional specialization}

In respect to the most popular professional specialization in firms and the evaluation of those employees' skills, most employees belong to the category of Professionals and Services staff (appr. 46\%) while the lower percentages refer to skilled craftsmen staff and the related professions as well as the senior management and executives. In more detail, the results are presented in the table that follows (Table 3).

Table 3. Most popular professional specialisation

\begin{tabular}{|c|c|c|c|c|}
\hline & Frequency & Percentage & $\begin{array}{c}\text { Valid } \\
\text { percentage }\end{array}$ & $\begin{array}{l}\text { Cumulative } \\
\text { percentage }\end{array}$ \\
\hline Senior managers and executives & 3 & 1.50 & 1.50 & 1.50 \\
\hline Professionals & 42 & 20.80 & 20.80 & 22.30 \\
\hline Technical staff and related professions & 23 & 11.40 & 11.40 & 33.70 \\
\hline Office employees & 27 & 13.40 & 13.40 & 47.00 \\
\hline Salesmen and Services staff & 51 & 25.20 & 25.20 & 72.30 \\
\hline Skilled craftsmen staff and related professions & 26 & 12.90 & 12.90 & 85.10 \\
\hline $\begin{array}{l}\text { Operators of industrial installations, machinery and } \\
\text { equipment and assemblers }\end{array}$ & 5 & 2.50 & 2.50 & 87.60 \\
\hline $\begin{array}{l}\text { Unskilled workers, manual workers and small-scaled } \\
\text { professionals }\end{array}$ & 23 & 11.40 & 11.40 & 99.00 \\
\hline Uncategorised staff & 2 & 1.00 & 1.00 & 100.00 \\
\hline Total & 202 & 100.00 & 100.00 & - \\
\hline
\end{tabular}

\subsubsection{Most Critical Professional Specialization}

As far as it concerns the most critical professional specialization with regard to firms' competitiveness, results have shown that most employees belong to the professionals and services staff while lower percentages concern 
the skilled craftsmen staff and the related professions, as well as the operators of industrial installations, machinery and equipment and assemblers. Worth mentioning is the increase of the percentage for the senior managers and executives (5\% increase) in relation to the most popular professional specialization. The results are given in detail in Table 4.

Table 4. Most critical professional specialisation

\begin{tabular}{|c|c|c|c|c|}
\hline & Frequency & Percentage & $\begin{array}{c}\text { Valid } \\
\text { percentage }\end{array}$ & $\begin{array}{c}\text { Cummulative } \\
\text { percentage }\end{array}$ \\
\hline Senior managers and executives & 13 & 6.40 & 6.40 & 6.40 \\
\hline Professionals & 50 & 24.80 & 24.80 & 31.20 \\
\hline Technical staff and related professions & 23 & 11.40 & 11.40 & 42.60 \\
\hline Office employees & 22 & 10.90 & 10.90 & 53.50 \\
\hline Salesmen and Services staff & 58 & 28.70 & 28.70 & 82.20 \\
\hline Skilled craftsmen staff and related professions & 18 & 8.90 & 8.90 & 91.10 \\
\hline $\begin{array}{l}\text { Operators of industrial installations, machinery and } \\
\text { equipment and assemblers }\end{array}$ & 2 & 1.00 & 1.00 & 92.10 \\
\hline $\begin{array}{l}\text { Unskilled workers, manual workers and small-scaled } \\
\text { professionals }\end{array}$ & 14 & 6.90 & 6.90 & 99.00 \\
\hline Uncategorised staff & 2 & 1.00 & 1.00 & 100.00 \\
\hline Total & 202 & 100.00 & 100.00 & - \\
\hline
\end{tabular}

\subsection{Qualitative research}

Firms operating in the region of Attica participated within the research focus groups especially from the following business sectors: food services; retail trade; technical advisor services; provision of professional training services, scientific support and consulting.

As mentioned during the first part of the focus groups discussions dealing with the characteristics of firms and the sectors they operate in, the prospects of each sector varies, since current economic crisis has created a climate of uncertainty, but also a climate of intense fluctuations. In particular, the adverse effects of the crisis are longterm for the sector of technical advisors, since their scope of action has shrunk due to the limitation of public investments. At the same time, significant reduction of private investments in real estate was also noted. On the contrary, the trend for the next trimester seems positive for the food service sector, which is noted mainly due to the seasonal increase in the consumption because of Christmas and New Year's Eve and not due to recovery processes of the sector. In the vocational education and consulting sector, the prospects in the domestic market are neutral but they are promising in the international market which seems to be a significant way out. Finally, in the trade sector there are some diversifications depending on the sub-sector. Thus, trade of Private Computers and software continues to be a dynamic sub-sector with promising prospects. The same does not go for the sub-sector of food and drink trade, where tendencies are estimated to be negative for the next trimester while for the same time period it is believed that there will be no alterations in the folk art trade.

Regarding the methods of recruiting and choosing the personnel, for the majority of sectors the most usual source for finding human resources is the family and friendly environment. For the sector of professional training services, the source to find the personnel needed are old trainees, beneficiaries of programs to fight unemployment (ex. Vouchers), but also students undergoing their practice internship. In any case, according to focus groups discussions, the most significant stage of recruitment seems to be the trial (test) period, as well as the Curriculum Vitae which gives a good picture of the candidates' profile.

During the second part of the focus groups discussions, special interested was given in the qualitative characteristics of human resources and whether those respond to the needs of modern greek businesses. In particular, in terms of employees' educational level, it was obviously evident that in the sectors of trade and catering the (educational) level is rather low since the employees are mainly secondary education graduates and to a small 
percentage Vocational Training Institutions (VTI) or Technological Educational Institute (TEI) graduates, while in the technical advisor services provision and professional training, the positions are covered mainly from Universities graduates and Master holders.

In terms of skills in high demand, it is shown that the majority of companies' management does not focus on the hard skills but rather to the non-typical (soft skills). This is actually depicted in the answers to the question of whether the management of the firm uses as a criterion in order to hire someone the degrees he/she holds.

Emphasis was given by some of the participants in the focus groups on the fact that holding a degree title does not mean that the candidate has all the knowledge and skills necessary to execute the work and tasks the working position entitles, but it is an indication that the candidate is more receptive to learning processes and will probably assimilate more easily the new knowledge each profession requires. However, important role in necessary typical skills holds the knowledge of a foreign language, especially in the trade sector but also in the sector of vocational training services, where actually a degree certifying the skills in ICT (Information and Communication Technologies) is positively assessed. Even though the specialized digital skills constitute an additional advantage for finding a job in the sector of technical advisor services, it does not constitute a typical skill in terms of a certified degree, but it is considered as an acquired skill that might have been developed through previous professional experience.

The views concerning the degree of importance of holding certifications from professional training programs seem converging. In particular, in all sectors, except the sector of professional training services provision, firm representatives have declared it to be of great importance. On the contrary, holding training programs titles is of minor importance in the sector of technical advisor services, since other candidates' characteristics are of high priority. Those characteristics concern mainly the tendency to cooperate and the degree of adaptiveness of the employee to the conditions and requirements of each working position.

This makes clear that the majority of Greek firms management departments seek for employees that attended educational programs, even though in some cases this is certified by a subordinate title, such as simple training programs. This view is the result of the belief that the necessary knowledge is acquired through the hands-on experience in each position.

As far as it concerns the non-typical skills, firms from the trade sector mention "prior experience" as a desirable skill, in particular for the administrative personnel and drivers.

In terms of skills, it is obvious that the necessary skills for firms in the sectors mentioned above are in majority horizontal (soft skills) with the main ones being: writing and oral communication skills; cooperation; speed; time management; problem and crisis management; safety management.

\section{CONCLUSIONS AND SUGGESTIONS}

Via the field research, the positive tendency of preserving the number of working positions in the last semester the research was conducted (2015), was noted, since for the majority of firms there have been no changes, while the percentage (24.8\%) of local stores where there has been an increase in the working positions is worth mentioning. On the contrary, the percentage of firms that seem to have decreased the job positions in relation to the previous semester is rather low (12.9\%).

On the other hand, the opinions brought-in during quantitative research give a particularly adverse climate, with firms' limiting their activity and therefore the working positions. The only exception is noted for the sector of food services and catering, where we expect favorable tendencies for the next trimester. However, it is worth mentioning that this is due to seasonal increase of the consumers' expenses due to Christmas and New Year's Eve and not due to the recovery of the sector. Also, in the trade sector, there seem to be differentiations depending on the 
sub- sector. Thus, the private computers and software sales is still a dynamic sub-sector with favorable prospects. The same does not go for the sub- sector of food and beverage sales where tendencies are estimated to be negative for the next trimester, while for the same time period no alterations are expected in the sector of folk-art sales.

However, during the time the quantitative and qualitative research was conducted, the majority of firms had no vacancies and only one small percentage of $18.3 \%$ mention that they have vacant positions to be filled. The greater demand is found in specializations such as professionals and office employees. As far as it concerns the number of vacant positions, the majority of the firms in Attica have an immediate need of one person, while very few have an immediate need for more than 3 persons.

Regarding the necessary training level of employees to cover the vacant positions, most firms ask for (minimum) the Secondary or University educational background. Here it is worth mentioning that at the current situation the personnel's educational level is lower, since most of the employees are mainly high school graduates. As far as it concerns the necessary working experience, the quantitative research has shown that for $1 / 3$ of the participants (companies) it does not constitute a significant selection criterion, since they do not look for employees with experience, while the remaining $2 / 3$ of the people involved in the research are allocated to those asking for candidates having 1, 2 or 5 years of experience. In terms of the qualitative research during focus groups discussions, it was noted that the experience is a basic skill for someone to cover each working position. This comes in total consensus with the belief of the majority of firms participating in the qualitative research, that typical skills are of lesser importance in relation to the non-typical ones. Emphasis was given by some of the participants in the focus groups on the fact that holding a degree title does not mean that the candidate has all the knowledge and skills necessary to execute the work and tasks the working position entitles, but it is an indication that the candidate is more receptive to the learning processes and will probably assimilate more easily the new knowledge each profession requires. In addition, there is clear need for foreign languages knowledge from countries of the Eastern Europe and Asia. This requirement often seems not to be covered adequately.

More comprehensive and analytical data for the degree to which desirable skills and qualifications are covered, were given by the analysis of quantitative data in the field research. Before we mention the main conclusions, it is worth mentioning that most employees belong to the category of professionals and people working in the provision of services, while lower percentages refer to skilled craftsmen staff and related professions, operators of industrial facilities, machinery and equipment and finally, assemblers. In terms of the employees, working already in the above job positions, the quantitative research has revealed the information below, in terms of certain skills adequacy:

1. Use of Greek language: it is noted that to a quite high percentage (45\%) employees are competent, while very few are incompetent (only 1.5\%).

2. Foreign languages: a significant percentage of the firms in the sample (32.7\%) seem to declare that competency is covered at a medium degree, while incompetency seem to have only $4.5 \%$. In relation to the arithmetic skills, most are competent enough, where $63.4 \%$ of the sample are scoring "very much".

3. Basic digital skills: most employees are relatively high competent, very few have low competency, while there is a percentage of $12.9 \%$ of the businesses that are not interested in such a skill.

4. Special digital skills: It is worth mentioning the significant high percentage of firms declaring that this is a skill that does not concern them (37.6\%).

5. Analytical thinking: for half of the sample this skill is very important, while only $8.4 \%$ declare incompetency or very small competency.

6. Critical thinking: same percentages of competency such as for analytical thinking.

7. Dissemination and processing of information: the human resources that have "high" or "very high" competency in this skill, are the majority. In relation to lifelong learning, there seem to be relatively high competency, while quite high (16.3\%) is also the percentage of firms not at all interested in this skill.

8. Interactive and communication skills: the majority of employees are competent to a percentage of $40 \%$, while very few are the incompetent ones with $1.5 \%$. 
It is worth mentioning that the skills of foreign languages knowledge, arithmetic competency, processing of information, dissemination of information and problem resolving seem to have a statistically significant difference in relation to the critical professional specialization per sector. In particular, the upper administration and management have the higher degree of competency in the use of a foreign language and arithmetic skill while the operators of industrial facilities the lower competency to the rest of skills. In particular the sector of transportation has the lowest degree of competency in specialized digital skills while constructions have the smallest competency degree in the rest of the skills.

Summing this study, it is worth mentioning that during the procedure of focus groups, the participants expressed the desire for skills like honesty, willingness, patience, and the will to learn, which are particular aspects of an individual's personality in the sense that they are mainly steady behavioral, thinking and emotional expression aspects and are differentiated from the skills that can be acquired. The personality of each individual is a primary criterion for hiring or even for his/her development within the firm, since incompetency in some of the skills might be covered via appropriate actions. In reference to covering inadequacy of skills, the ways firms decide to deal with that are based on further professional education/training of the personnel. The discussion about the existing educational and training system in our country focused on whether it is in line with the labor market and whether it prepares appropriately trainees as future professionals. Common conclusion of all discussions was that the educational system as it is, lacks in providing the trainees with the appropriate knowledge, qualifications and skills to a satisfactory degree in order to cover the demands of the labor market.

In this context what is needed is to reform both the basic educational system and the systems for the initial and lifelong learning training programs, taking into consideration the goals of national policies for the development of human resources, empowerment of employment and entrepreneurship. As a matter of fact, the vast majority of focus groups participants considers the social partners must have an active role and undertake priorities aiming at interconnection of education/training with the entrepreneurial community, at strong specialization and at deepening and constant updating of educational programs, according to the market evolutions.

To this end, a series of institutional interventions are needed with the most important one being the upgrade of educational programs taking into consideration the needs of the businesses, as those are tracked systemically by Employment Observatories, which can operate via a network of entities and organizations and will have as objective the gathering, research and analysis on a systemic/periodical basis of micro and macro-economic data that concern the labor demand as this is formed and evolved.

\section{REFERENCES}

1. Acemoglu, D., Akcigit, U., Harun, A., Bloom, N., \& Kerr, W. (2018). Innovation, Reallocation, and Growth. American Economic Review, 108(11), 3450-3491. http://dx.doi.org/10.1257/aer.20130470

2. Aghion, P., Akcigit, U., Bergeaud, A., Blundell, R. \& Hemous, D. (2019). Innovation and Top Income Inequality. The Review of Economic Studies, 86(1), 1-45. https://doi.org/10.1093/restud/rdy027

3. Arkolakis, C., Ramondo, N., Rodríguez-Clare, A., \& Yeaple, S. (2018). Innovation and Production in the Global Economy. American Economic Review, 108(8), 2128-73. http://dx.doi.org/10.1257/aer.20141743

4. Barley, W., Treem, J., \& Kuhn, T. (2017). Valuing Multiple Trajectories of Knowledge: A Critical Review and Agenda for Knowledge Management Research. Academy of Management Annals, 12(1). https://doi.org/10.5465/annals.2016.0041

5. Becker, B. E., Huselid, M. A., \& Ulrich, D. (2001). The HR Scorecard: Linking People, Strategy and Performance (235 p.). Massachusetts: Harvard Business Press.

6. Bartik, T. (1991). Who Benefits from State and Local Economic Development Policies?. Kalamazoo: W.E. Upjohn Institute for Employment Research. https://doi.org/10.17848/9780585223940

7. Burns, P. M. (1999). Hard-skills, soft-skills: undervaluing hospitality's 'service with a smile'. Progress in Tourism and Hospitality Research, 3(3), 239-248. https://doi.org/10.1002/(SICI)1099-1603(199709)3:3\%3C239::AID-PTH80\%3E3.0.CO;2-2

8. Caloffi, A., \& Mariani, M. (2011). Shaping regional policy responses: the design of innovation poles. Policy Studies, 32(4), 413-428. https:// doi.org/10.1080/01442872.2011.571857

9. Cosh, A., Hughes, A., Bullock, A., \& Potton, M. (2003). The relationship between training and business performance (95 p.). England: DfES.

10. Crowley, S., Hager, P., \& Garrick, J. (2000). Subcontractors in the Australian Construction Industry: No Small Business. In Working Knowledge: Productive learning at work (International Conference) (pp. 87-95). Sydney: University of Technology.

11. Du Plessis, M. (2007). The Role of Knowledge Management in Innovation. Journal of Knowledge Management, 11(4), 20-29. http://dx.doi. org/10.1108/13673270710762684 
12. Field, L., \& Mawer, G. (1996). Generic Skill Requirements of High Performance Workplaces. Sydney: DTEC.

13. Fuller, B., \& Bradbard, D. (2009). An Entrepreneurial Application of a Geographic Information System. Decision Sciences Journal of Innovative Education, 7(1), 163-170. https://doi.org/10.1111/j.1540-4609.2008.00211.x

14. Goodchild, M. F. (2010). Twenty years of progress: GIScience in 2010. Journal of Spatial Information Science, 1. http://dx.doi.org/10.5311/ JOSIS.2010.1.2

15. Hospitality Training Foundation (2000). Skills and Employment Forecasts 2000. London: HtF.

16. Howell, W. C., \& Cooke, N. J. (1989). Training the human information processor: A review of cognitive models. In Goldstein, I. L. (Ed.). Training and development in organizations (pp. 121-182). San Francisco: Jossey-Bass.

17. Jao, C. (2010). Decision Support Systems. Intech.

18. Kalogirou, G. (1998). Competitiveness: Theoretical Queries and Strategic Answers. Athens: George Dardanos.

19. Keenan, P. B. (2008). Geographic information and analysis for decision support. In Burstein, F., \& Holsapple, C. W. Handbook on decision support system. New York: Springer.

20. Kluve, J. (2010). The effectiveness of European active labor market programs. Labour Economics, 17(6), 904-918.

21. Korczynski, M. (2002). Human Resource Management in the Service Sector. Basingstoke: Palgrave.

22. Kourliouros, H. (2009). Course on theories of space: Economic Geographies of Production and Development. Athens: ed. Greek Letters.

23. Lambrianidis, L. (2001). Economic Geography. Athens: Patakis Eds.

24. Lianos, Th., \& Benos, Th. (1998). Macroeconomic Theory and Politics. Athens: Editions of Benos.

25. Manning, L. (2013). A knowledge exchange and diffusion of innovation (KEDI) model for primary production. British Food Journal, 115(4), 614-631. http://dx.doi.org/10.1108/00070701311317883

26. Marakas, G. (2002). Decision Support Systems (2nd ed.). Prentice Hall.

27. Matheus, R., Janssen, M., \& Maheshwari, D. (2018). Data science empowering the public: Data-driven dash-boards for transparent and accountable decision-making in smart cities. Government Information Quarterly. https://doi.org/10.1016/j.giq.2018.01.006

28. McBride, K. A., MacMillan, F., George, E. S., \& Steiner G. Z. (2019). The Use of Mixed Methods in Research. In Liamputtong, P. (Eds.). Handbook of Research Methods in Health Social Sciences. Springer: Singapore.

29. Mc Cann, P. (2002). Urban and Regional Development. Athens: Kritiki Publications.

30. Mitchell, E. S. (1986). Multiple triangulation: a methodology for nursing science. Advances in Nursing Science, 8(3), 18-26.

31. Montoya, R., \& Peñalvo, G. (2018). Co-creation and Open Innovation: Systematic Literature Review. Comunicar, 26(54). https://doi. org/10.3916/C54-2018-01

32. Morse, J. M. (1991). Approaches to Qualitative - Quantitative Methodological Triangulation. Nursing Research, 40(1), 120-123.

33. National Labor and Human Resources Institute (NLHRI - EIAED) (2015). Annual Report: Mechanism for Diagnosing Labor Market Needs.

34. National Labor and Human Resources Institute (NLHRI - EIAED) (2018). Annual Report: Mechanism for Diagnosing Labor Market Needs.

35. Nickson, D., Baun, T., Losekoot E., Morrison A., \& Frochot, I. (2003). Skills, organisational performance and economic activity in the hospitality industry: a literature review. England: SKOPE.

36. Oikonomakis, G. \& Markaki, M. (2016). The sectoral structure of the Greek economy and the question of "production reconstruction: An analysis with the Input-Output Method. Utopia, 115 (January-February 2016).

37. Ozturk, S., \& Sozdemir, A. (2015). Effects of Global Financial Crisis on Greece Economy. Procedia Economics and Finance, 23, 568-575. https://doi.org/10.1016/S2212-5671(15)00441-4

38. Papa, A., Dezi, L., Gian, L., Jens, G., \& Miglietta, N. (2018). Improving innovation performance through knowledge acquisition: the moderating role of employee retention and human resource management practices. Journal of Knowledge Management. https://doi. org/10.1108/JKM-09-2017-0391

39. Papadimitriou, D., Nikiforos, M., \& Zezza, Z. (2015). Greece, Conditions and Strategies for Economic Recovery. Levy Economics Institute of Bard College.

40. Pines, S., Koutek, S., \& Shatkin, L. (2011). EZ Occupational Outlook Handbook. JIST Publishing

41. Ř́hová, H. (2016). Using labour market information: guide to anticipating and matching skills and jobs (vol. 1) (128 p.). Luxembourg: Publications Office of the European Union.

42. Rodrigues, J., Simão, A., \& Antunes, C. (2011). A GIS-based multicriteria spatial decision support system for planning urban infrastructures. Decision Support Systems, 51(3), 720-726. https://doi.org/10.1016/j.dss.2011.02.010

43. Rosenthal, S., \& Strange, W. (2005). The Geography of Entrepreneurship in the New York Metropolitan Area. New York: FRBNY Economic Policy Review.

44. Setiawan, M. (2018). E-Business, the impact of regional growth on the improvement of Information and Communication Development. Journal of Physics: Conference Series, 1007(1). https://doi.org/10.1088/1742-6596/1007/1/012044

45. Schumpeter, J. A. (1934). The Theory of Economic Development. An Inquiry Into Profits, Capital, Credit, Interest and the Business Cycle (255 p.). Harvard Economic Studies, 46.

46. Spilsbury, D. (2002). Learning and training at work. Nottingham: DfES.

47. Storper, M, \& Scott, A. (1992). Pathways to industrialization and regional development. New York: Routledge.

48. Sugumaran, R., \& Degroote, J. (2011). Spatial Decision Support Systems: Principles and Practices (508 p.). CRC Press.

49. Tian, M., Deng, P., Zhang, Y., \& Salmador, M. (2018). How does culture influence innovation? A systematic literature review. Management Decision, 56(5),1088-1107. https://doi.org/10.1108/MD-05-2017-0462

50. Turner, R. (2004) Towards a Structural Model Connecting Hard Skills, Soft Skills and Job Conditions and the IS Professional: the Student Perspective. Australia: Victoria University. https://doi.org/10.28945/2782

51. Varoufakis, Y. (2017). Adults in the Room: My Battle with Europe's Deep Establishment (560 p.). New York: Farrar, Straus and Giroux.

52. Walras, L. (1954). Elements of pure economics or the theory of social wealth. Homewood.

53. Walras, L. (1992). Etudes déconomie politique et appliquée. Paris: Economica. 
54. Walras, L. (1993). Théorie mathématique de la richesse sociale. Paris: Economica.

55. Wang, A., \& Guo, D. (2018). Technical and vocational education in China: enrolment and socioeconomic status. Journal of Vocational Education \& Training, 71(4), 538-555. https://doi.org/10.1080/13636820.2018.1535519

56. Wilgaard, P. (2019). Regionalism and Institutional Competitiveness. European Urban and Regional Studies, 1-19.

57. Yang, K., \& Miller, G. (2008). Handbook of Research Methods in Public Administration. New York: CRC Press, Taylor \& Francis.

58. Zheng, Y., Hatakka, M., Sundeep, S., \& Andersson, A. (2018). Conceptualizing Development in Information and Communication Technology for Development (ICT4D). Information Technology for Development, 24(1), 1-14. https://doi.org/10.1080/02681102.2017.1396020 